\title{
States' Rights and Economic Development
}

\section{By Chris Thompson}

\begin{abstract}
The United States' growing inmersion in the global marketplace has great significance in the area of economic development. The current lack of agreement between the federal and state levels of government concerning their respective roles in attracting foreign investment could possibly have serious consequences as America becomes further integrated into the world economy. A national discussion between government officials, the private sector, and experts in academia needs to take place to determine a comprehensive course of action for the nation. Such a national plan, however, does not require the nationalization of economic development planning. Indeed, to better plot future economic development in the global environment, it is useful to examine the two competing forces driving state and federal economic development planning, states' rights and centralization, and to assess the current status of these ideologies.
\end{abstract}

The rise of the global marketplace has had a significant impact on the economic development of the United States. Governments at the national and state levels must be concerned not only with encouraging business within their borders but also enticing investment and commerce on an international scale. Currently, little coordination exists between the two levels of government to ensure that development policies are being implemented in the most efficient and productive manner.

In light of the growing importance of the world economy to U.S. business growth, new economic development strategies are needed to address this reality. At the very least, some coordination between economic development policy actors at the respective levels of government might be in order. However, before a dialogue

Chris Thompson graduated magna cum laude from the University of Tennessee at Chattanooga in May 1998, obtaining a B.S. with Honors in Political Science. He has since worked in the U.S. Senate, first in the office of Senator Fred Thompson of Tennessee and most recently in the office of Senator Judd Gregg of New Hampshire. Mr. Thompson graduated from The George Washington University, with a Master's degree in Public Administration in May 2002. can be successfully initiated, an examination of the differing ideologies on economic development by state and federal government must take place. Without a strong grasp of the reasoning that led the two levels to develop economic policy independently of each other, no comprehensive, workable resolution can be attained. Accordingly, state and local governments must come to a mutual understanding regarding their particular roles in the nation's overall economic development.

To understand what changes need to take place, it is first necessary to examine why national and state governments adopted their current, differing development ideologies. Arguably, the divergence is based on tensions that have been in existence since the nation's founding. One viewpoint holds that the ideas of "competitive federalism" serve as the best template for economic development policy. This belief tends to coincide with a states' rights mentality: states are entitled to conduct themselves, their governments, and their development programs in whatever way will most benefit their constituency as long as these plans are constitutional. However, the supporters of a more unitary model might well contend that a national, centralized policy is more beneficial in ensuring a more fair and equitable system for all citizens, regardless of where they live.

Examples of these differing ideologies are evident in several recent economic development policies. At the national level, the federal government has entered into several international agreements such as the General Agreement on Trade and Tariffs (GATT) and the North American Free Trade Agreement (NAFTA) in order to 


\section{STATES' RIGHTS AND ECONOMIC DEVELOPMENT}

provide a more favorable market for U.S. goods. This action would indicate a highly centralized economic development plan for the country as a whole. However, the actions of state governments over the past several decades, offering generous tax incentives for foreign investors as well as the opening of development offices overseas, have created a competition among themselves to entice businesses to choose one state over another.

The concurrent pursuit of both agendas may actually prevent either system from dominating policy. 'The problem lies in the fact that different government levels now tend to act independently of each other. This makes it quite difficult for the United States to present a strong, unified economic front to the world when policies are often implemented that seem to be at odds. For example, some states have programs that actively seek out lowskill industries like textiles and manufacturing while national initiatives such as NAFTA make it easier for these jobs to be relocated to Mexico. The emergence of this apparently contradictory situation is rooted in the history of the two paradigms of American federalism and should be examined both to properly view the present situation and to arrive at possible solutions.

\section{Greater State Autonomy and Economic Development}

Given the competitive nature of the free market, states tend to exhibit an adversarial relationship with one another when implementing economic development strategies. Competition inheres in the incentive packages used by states to lure businesses from one state to another as well as in those used to attract foreign investment. Several states have even pursued foreign trade relations to the extent of opening economic development offices around the world. Tennessee, through its Department of Economic and Community Development's Office of International Affairs, has a number of foreign outposts, including one in Japan (Office of International Affairs, website). Indeed, Katherine Barrett and Richard Greene note, "more states have offices in Japan than they do in Washington, D.C... (and) many states have at least three or four offices." These offices serve not only to attract foreign investors to the states but also to open doors for states' products overseas. Barrett and Greene remark that Oklahoma has an office in India "to help [Oklahoma's] companies sell their oil and gas products there" (Barrett and Greene, 1990, 44). While there are a number of arguments for and against these activities, the fact that they have occurred reflects a belief among the states that they are and should be the architects of their own economic destinies. As such, the practice of competitive economic development among the states represents an ideology closely aligned with a traditional states' rights movement.

\section{States' Rights: A Background}

One of the earliest debates of American federalism had to do with the distribution of power between national and state governments. Indeed, in the first attempt at a federal system, the Articles of Confederation placed the majority of power in the hands of state legislatures. Fearful of centralized power, the framers of the Articles did not provide for a chief executive nor did they grant taxing authority to the national government. Under the plan of the Articles, the national government was clearly at the mercy of the states.

The Articles were subsequently replaced with the Constitution in 1789, which placed enhanced authority in the national government and supremacy in the Constitution. The final amendment in the Bill of Rights further defined the relationship between the states and the national government. Indeed, the $10^{\text {th }}$ amendment expressly provides that any "puwers not delegated to the United States by the Comshimition, nor prohibited by it 
to the States, are reserved to the States respectively, or to the people (italics added). Such stipulations should not be taken lightly when examining competitive federalism and its underlying issues of states' rights.

The contemporary assertion of states' rights began to emerge in the late 1970s and early 1980s. Although this resurgence began during the Carter Administration, the large-scale devolution of federal power and responsibility to the states is widely regarded to have been championed by President Reagan. The President, along with the Republican Party, regularly pointed to the evils of an outsized national government and asserted that better accountability and efficiency could be achieved by returning power to the states. Reagan's economic development plans, what came to be popularly termed "New Federalism," sought to accomplish this through the transfer of many federal programs to the states.

In recent years, Congress has continued this agenda by attempting to limit unfunded mandates handed down by the national government to the states for example. For their part, states have taken a number of initiatives toward greater state autonomy. The drastic changes to the national welfare system in 1996, which used a block grant system to turn many decision-making duties over to the states, is one of the most striking illustrations of this devolution.

Inherent in the states' rights movement is the notion that states can handle many governmental tasks better than the federal government and, therefore, should have a greater share of power in the federal system. This assertion comes after many years of restructuring by state governments, including the adoption of stricter accounting, spending, and budgeting practices. Improved fiscal controls, combined with restraints on the federal government's abilities to increase taxes and other fees, have fostered a view of state governments as viable alternatives to federal control. As John Shannon and James Kee observe, Since 1978 . . A American federalism has veered sharply away from [the] centralizing course towards greater governmental competition - a surprising development that may be traced largely to the disappearance of the once formidable fiscal advantage that the national government enjoyed over the state-local sector.

(Shannon and Kee, 1989, 5).

Using operational norms drawn from the business sector, these recent changes have brought a higher level of respectability to state government operations. Until the 1970s, states were viewed as mismanaged, inept organizations. It was not uncommon for citizens to regard states as corrupt governments that often had a difficult time keeping track of where tax dollars were spent. The poor operational conduct of many state governments resulted in the gravitation of many state activities to the national level.

However, over time, a reorganization of state governments took place, bringing about the improvements recognized today. A new era of competitive federalism has taken hold as these "remolded" state governments have challenged the national government for greater autonomy. As state governments have made the necessary changes to reemerge as viable players in the federal system, they have likewise initiated a series of aggressive, competitive economic development plans. Bolstered by their successes in building governments perceived as more responsible, efficient and responsive than their national counterpart, states have begun to assert the notion that they can also do a better job ensuring their own economic vitality.

\section{Unifying America's Economic Development}

The national government, in contrast to the state governments, presents the United States to the world as just 
STATES' RIGHTS AND ECONOMIC DEVELOPMENT

that-united under one banner. Such a unified image is often considered a positive attribute, recalling the adage that "the whole is more than the sum of its parts." However, the national government also tends to act paternally towards the states, trying to protect them from the economic dangers of the world market. The rationale for such an attitude stems from the idea that since the federal government works on behalf of all, regardless of state boundaries, it also has advantages of political strength and presence on the world stage that states do not. This viewpoint is not without merit, since the national government has been assigned unitary powers by the Constitution that are necessary for the conduct of international affairs. The idea of unified government and centralization of power at the national level for the purposes of foreign relations are also part of the same doctrine out of which notions of competitive federalism and states' rights evolved.

\section{Centralization: A Background}

The balance of power between a strong central government and decentralized power of the several states was a central feature of the constitutional debate. In a letter to Thomas Jefferson, James Madison asserted that "the objects of the Union could not be secured by any system founded on the principle of a confederation of Sovereign States." Madison continued, "Such a check on the States appears to me necessary-1. To prevent encroachments on the General authority. 2. To prevent instability and injustice in the legislation of the states" (Madison, 1787, 64). These arguments form the bedrock for proponents of nationalization of government functions, especially when expanded to include problems of social inequality.

Throughout American history, the impulse towards a stronger centralized government has usually occurred in response to national emergencies. Along with the na* tionalization of functions during the Civil War and the two world wars, periods of civil strife have also prompted the drive towards centralization. For example, in response to the Great Depression, President Franklin D. Roosevelt expanded the bread th and scope of the federal government through the executive and legislative initiatives of the New Deal. These laws and regulations removed many banking, welfare, and labor functions from state control and brought them under the oversight of the federal government. Likewise, 30 years later, the Civil Rights Act, passed during President Lyndon Johnson's administration, greatly expanded federal oversight of civil rights within the states and offered federal remedies to the tide of abuses that African-Americans had long suffered under the "Jim Crow" laws of the South. During this same period, the Great Society program launched a multitude of domestic policy initiatives that sought to address national social problems such as poverty and economic inequity by implementing sweeping programs at the federal level. Many of the policies put into place during the New Deal and Great Society are still in effect today.

\section{Looking at Two Competing Economic Development Ideologies}

It is possible to make compelling arguments for the pursuit of a national economic policy from the standpoint of either state-centered or national-centered economic development. The debate for one or the other pits the virtues of competition and innovation against those of equity and unity. Although these notions are important American ideals, and the achievement of each or all would represent positive accomplishment, either in theory -favoring either the state or the national level-could produce negative effects if taken to extremes. Revicwing the positive and negative arguments for ewh loctrine, it can be 


\section{POLICY PERSPECTIVES}

argued that neither position is comprehensive enough on its own merits to satisfy the diverse needs of the state and national economies.

\section{State Economic Planning}

The resurgence of states' rights has promoted the creation of new economic development plans within states. As states have begun to diversify, to find new ways to expand their tax bases, and to rely more on their own various tax revenues than on federal dollars to finance the delivery of goods and services, they have used taxing powers as tools to promote business within their borders (Dilger, 2000, 102). Proponents of state-controlled economic development contend that the close proximity of state governments to the affected economies better positions the states to design the programs to meet local needs. Further, invoking the benefit principle of taxation, there is a belief among state's rights advocates that state and local tax dollars should be used to directly benefit those people from whom the taxes were collected.

Regarding foreign investment within particular states, significant debate exists over whether or not individual state governments should compete for and promote international business by creating initiatives to attract foreign investment and opening field offices abroad. These practices gained momentum in the 1980s, when a number of states established economic liaison offices in Pacific Rim countries, particularly in Japan. While some analysts hold that this practice constitutes state interference in foreign policy, a political sphere normally reserved for the national government, others believe that states may play a legitimate role in the exercise of international trade policy. As Conlan contends, "by the 1980s and 1990s, most states had established the political and institutional foundation needed to respond to rapidly changing global and intergovernmental conditions and to assume new responsibilities in a devolutionary era" (Conlan, 1998, 391).

In fact, this belief seems to be expanding, with states continuously exploring new ways to entice foreign firms and to recruit foreign labor to their borders. Perhaps most indicative of this trend are the recent statements by Iowa officials encouraging Mexican immigration to fill jobs within their state (Armas, 2000, $1 \mathrm{~g}$ ). Iowa's foray into immigration policy - a policy area traditionally under the purview of the federal government - underscores the belief of state governments that they are capable of addressing their economic development needs both domestically and globally and should be free to do so.

State governments are also utilizing their primary powers in such policy areas as education, planning and zoning, and taxing authority to strengthen their economic development positions. As Stephen Goetz and David Freshwater argue, "state economic development policy is increasingly being seen as a potentially significant factor influencing development patterns.... They have the power to influence many of the factors important to economic development" $(2001,2)$. This assertion holds especially true with education. Since the states control the curriculum and funding of education, they are increasingly using their educational systems as an integral element of their economic infrastructure, especially in the information age, where knowledge has rapidly become a very valuable commodity in an increasingly service-oriented global economy. Other factors traditionally used to lure manufacturing from one state to another, such as planning, zoning, and tax abatement, are now being used to attract businesses from around the world. Combined with the high level of education in the United States, these state-controlled factors have 


\section{STATES' RIGHTS AND ECONOMIC DEVELOPMENT}

taken on a significant importance in the international economic arena.

Because states exercise significant control over factors critical to economic development, state governments are better positioned to quickly respond to changes in the economy. However, control can also lead to misuse, which is illustrated in the overuse of one of the most common perquisites: tax incentives. Tax incentives and abatements are a strong factor in a business's choice of location but their long term-benefits are debatable. The fact that states are so flexible and adaptable has contributed to the proliferation of tax perks and pushed increasingly competitive states to offer lucrative tax reductions in order to successfully compete for business.

Some scholars believe, that taken to an extreme, tax abatements can initiate a downward spiral where costs far outweigh the short-term benefits. Paul Kahan, reviewing the well-publicized building of the Mercedes-Benz plant outside of Tuscaloosa, Alabama, notes that the state offered incentives totaling $\$ 165,000$ for every new job created by the plant (Kahan, 1998, 23). These incentives often come from local property tax exemptions awarded by the state and from waived corporate taxes. Foregoing these funds, especially in the instance of property taxes, can arguably be said to have a negative impact on a locality's services, such as public schools. Additionally, incentives have traditionally been reserved for new business entrants into the state, not those currently located there. These practices have lead to an outcry from "native" industries which contend that these perks should be extended to them as well. Alabama's Industrial Development Authority experienced such a backlash and was taken to court for its practices with Mercedes-Benz and the accompanying feeder industries (Kahan, 1998, 24).

Further, as Terry Buss has observed, competition for economic development between the states has in some cases gone to such an extreme as to advance beyond sensible competition; instead, "states find themselves at war with one another" (Buss, 2001, 90). Increasingly, the unique economic development programs that formerly distinguished one state from another have been duplicated across the nation. Additionally, many of these programs tend to be cumulative, with new tax incentives added onto an increasingly long list of perks expected by industry. The use of tax incentives has similarly grown in response to national attempts at economic development. As Buss notes, "the situation appears to be worsening: new national policies - for example the North American Free Trade Agreement - and recruitment of foreign firms are forcing states to adopt new forms of tax incentives and to increase use of existing programs" (Buss, 2001, 90). Finally, since the federal government underwrites many of the incentive programs, states governments are more likely to treat this strategy as cost-free. But when tax bases are restricted and government revenues are foregone in the name of over-inflated incentives, shortages in governmental funds may not be far behind.

\section{A Unified, Centralized Planning System}

While there is little argument about whether the competition between states is real, there is much debate as to whether the incentives and perks offered by state governments have a positive or negative effect on the nation as a whole. It is from this standpoint that the current argument for centralized planning emerges. Because states are chiefly responsible for many of the incentives used to attract businesses to their borders (including education, infrastructure, and tax environment), supporters of states' rights argue that states should likewise be allowed the au- 
POLICY PERSPECTIVES

tonomy to pursue the best interests for their economies.

On the other end of the spectrum, however, are those who contend that domestic economic development should be directed from the national level, especially when foreign investment is concerned. Underscoring the advantages of a more centralized system, supporters of this unitary view note the great disparities in the relative levels of education, income, and poverty around the country and argue that the present competitive nature of states only exacerbates the problem.

Proponents of this ideology also assert that states are practicing a zero-sum game from a national standpoint because incentives often attract only businesses from other states. Although the winning state may enjoy benefits, the losing state is left with unemployed workers and shrinking tax rolls. Further, proponents argue that the ostensible "victor" obtains little more than an empty victory, since the jobs gained by the relocation are paid for with costly tax abatements and other incentives. Opponents of the current competitive structure would argue that the short-term costs of tax incentives not only come out of the taxpayers' pocket, but can also shrink the revenue left for education and other services.

There are some who believe a centralized economic development plan would benefit the United States domestically as well as in the world market. Supporters of nationalized economic planning argue that many social ailments such as poverty and unemployment could be solved with a single, concerted effort rather than disjointed, competing, and potentially counterproductive programs. Bruce Jansson and Susan Smith contend that,

Economic inequality has grown dramatically in the past three decades. The restructuring of corporations, loss of manufacturing jobs, and transfer of jobs abroad have placed millions of Americans in economic uncertainty... It is not clear whether state or local governments are positioned to address these problems without federal guidance, even when given federal resources. (1996, 373)

Other supporters of nationally controlled economic development suggest that states and localities limit their focus to their traditional services. B. Guy Peters has argued that states should not focus on offering special incentives and credits but instead should work to excel in providing infrastructure components such as roads, water, and sewers. In Peters' view, the broader aspects of proactive economic development should properly fall under the purview of the national government. For Peters, the national government would be better able to implement a program to meet the majority of needs, including federal government grants for industry modernization, a trade policy that would protect American businesses from outside competition, some deregulation of U.S. industry, increased research and development funding, and comprehensive industrial and social policies targeting specific U.S. regions (Peters, 1999, 211-13).

The federal government plays a crucial role in bringing foreign investment into the United States, due most notably to its Constitutional power to negotiate treaties. Although several states have economic development plans that include international business recruiting, the federal government still commands the greatest power in this area. Under the auspices of NAFTA, the granting of Most Favored Nation (MFN) status, and many other international trade agreements, Washington has steered the United States' course on the world market. These pacts have reduced the impediments for U.S. businesses to compete in foreign markets and allowed the federal government to set conditions by which international businesses may enter the American market. The creation and implementation of these agreements has 


\section{STATES' RIGHTS AND ECONOMIC DEVELOPMENT}

tended to be heavily controlled at the national level, where relations with foreign governments (and, therefore, their regulatory and trade structures) have traditionally resided.

The benefits of uniformity and equity that are part of the benefits of a unitary economic development system also are the source of its shortcomings. A centralized program, with a national focus, tends to be less responsive to economic problems in individual states and localities. As for equity, this goal comes at the sacrifice of innovation because programs targeted to certain areas or industries are more likely to be rejected as valid development options in favor of broad, across-the-board, redistributive policies. Additionally, unless a large bureaucracy of federal employees with considerable discretion is based in every state and metropolitan area, it is doubtful that any federal program can accommodate the peculiarities of each area's economic climate.

\section{Towards A Coordinated Intergovernmental Economic Development}

Currently, international economic development in the United States is being advanced along two distinct but interrelated tracks at the state and federal levels. Although there may be little harm in this situation, a more coordinated national economic development would favor neither the state nor national governments assuming the majority of power.

The states have made great strides in retooling their governments and have become more receptive and flexible to modern needs in the process. Since state governments have adopted many practices of the business world, it seems possible that economic competition could work to governments' benefit. As free markets have repeatedly demonstrated, the dynamics of fair competition tend to promote improved products and services. Competitive economic development would let state and local governments compete to attract the best economic opportunities for the citizens. Competitive economic development between the states in the international marketplace might very well result in a better infrastructure, improved educational system, and an enhanced quality of life for the citizens of the states.

Concurrently, centralization has a valid role in economic development at the national level because the federal government is best positioned to represent the collective economic interests of the United States in the global economy. As Edward Hill states, "the debate on the federal role in economic development is more about the degree and type of federal involvement than about the fundamental legitimacy of that involvement" (Hill, 1998, 301). As 50 separate entities, excluding large and quite diversified states such. as California, Texas, and New York, states do not command a powerful presence on the world scene. However, joined together under one banner, the states comprise an economic power that has been quite successful at advancing its interests in the world economy.

The ability of the U.S. federal system to synthesize diversity and unity allows the government to be an economic powerhouse. This system of government allows more tools for economic development to be used than if the United States consisted of one homogenous, national government. As O'Toole points out, "Even as globalization offers the prospect of changing the national game ... evidence abounds that the American experiment remains a model and a source of ideas for the future" (O'Toole, 2000, 334). However, if the United States is going to remain at the forefront of international development, it must continuously alter its policies and re-examine traditional notions about proper roles of state and national government in this system of "federal economic development." 
In order to facilitate this effort, more needs to be done to foster intergovernmental coordination that can avert the pitfalls and problems noted above. Successes can be realized when coordination takes place. Hill points to a 1996 National Academy of Public Administration study that found "congressional power-coupled with a close working relationship between a state's delegation and local leadership, plus a sound development strategy-played a critical role in bringing two successful development efforts to scale . . in Tupelo, Mississippi, and Cleveland, Ohio" (Hill, 1998, 306).

Such cooperation should play an integral part in coordinating what has proven to be two very successful, if presently divergent, ideologies of economic development: that of states' rights and of centralized, national policy. As Peters remarks, "a more comprehensive approach ... (to) competitiveness in the international marketplace should be adopted" (Peters, 1999, 211-13). While some may come to the conclusion that sustained interaction and cooperation would defeat the Founders' purpose of dual sovereignty, deliberate study, planning, and implementation of a communicative framework could instead be a way to prevent accusations of intergovernmental intrusion. It is plausible that, through good plans and open lines of dialogue, an economic development structure surpassing even what the United States currently enjoys could be created without infringing on the bedrock principles of American federalism.

\section{Conclusion}

The definition of the respective roles that the national and state governments should play in economic development, especially in the international marketplace, is an important component in any attempt to improve upon current economic development practices in the United States. One option would have the national government using its powers to open the doors to interna- tional development and then stepping aside unless problems arise with foreign interests or between the states. A plan that reserves a larger role for the national government, such as McGahey proposes, that "encompasses state strategic planning and accountability yet recognizes the need for national coordination of policy" could also be viable (Hill, 1998, 307).

Whatever is decided, it will quite possibly lead to a new system of competitive economic federalism, one that is less apt to negatively affect the citizenry by coordination between the respective economic development interests of the federal and state governments. A working dialogue between officials at all levels of the U.S. federal system, the business sector, and experts in academia must begin to develop clearly defined but flexible roles for the various actors of economic development policy. The present decentralized system has worked rather well and restructuring of development policy may only need to work at the edges of the current framework, notably in the areas of cooperation.

Nonetheless, it is also arguable that major mishaps have occurred due to the lack of coordination between state and federal interests. It is this problem of coordination that must be rectified and to do so requires some form of agreement between the various governmental parties and the business sector. The ability of the United States to promote its economic interests in the growing international marketplace could well be hindered if coordination cannot be achieved to present an effective, unified front to the world economy while at the same time allowing states to pursue their own economic destinies. 


\section{STATES' RIGHTS AND ECONOMIC DEVELOPMENT}

\section{REFERENCES}

Armas, G. C. (2000, December 24). Iowa gearing up to recruit workers. Omaha World-Herald, $1 \mathrm{~g}$.

Barrett, K., and Greene, R. (1990, April 17). States: Over there, over there. Financial World, 159, 44.

Buss, T. F. (2001). "The effect of state tax incentives on economic growth and firm location decisions: An overview of the literature." Economic Development Quarterly, 15, 90-105.

Conlan, T. (1998). The future of reform. American Intergovernmental Relations. Washington, DC: CQ Press.

Dilger, R. J. (2000). The Study of American federalism at the turn of the century. State and Local Government Review, 32, 98-107.

Goetz, S. J., and Freshwater, David. (2001, February). State-level determinants of entrepreneurship and a preliminary measure of entrepreneurial climate. Economic Development Quarterly, 58-70.

Hill, E. W. (1998, November). Principles for rethinking the federal government's role in economic development. Economic Development Quarterly, 12, 299312 .

Jansson, B. S. and Smith, S. (2000). Articulating a "new nationalism" in American social policy. American Intergovernmental Relations. Washington, DC; CQ Press.

Kahan, P. R. (1998, Summer). Working with business incentives. Journal of Property Tax Management, 10,22-31.

Madison, J. (2000). "James Madison explains the Constitution to Thomas Jefferson." Principles and practice of American politics. Washington, DC: CQ Press. Excerpted from a letter to Thomas Jefferson dated October 24, 1787.

O'Toole, L. J. (2000). American Intergovernmental Relations. Washington, DC: CQ Press.

Peters, B. G. (1999). American public policy: Promise and performance New York: Seven Bridges Press.
Shannon, J., and Kee, J. E. (1989, Winter) The rise of competitive federalism." Public Budgeting \&Finance: $5-36$.

State of Tennessee, Office of International Affairs. Website. www.state.tn.us/ecd/idg.htm. 

